\title{
Evaluation of the Elderly'S Profile with Diabetes Mellitus in Primary Health Care
}

\begin{abstract}
Natália Pinheiro Fabrício', Natália Daiana Lopes Sousa1, Jayana Castelo Branco Cavalcante de Meneses ${ }^{1}$, Naanda Kaanna Matos de Souza1, Ilara Parente Pinheiro Teodoro1,2, Mariana de Morais Fortunato1, Thiaskara Ramile Caldas Leite1, Jucier Gonçalves Júnior ${ }^{3}$, Vitória de Cássia Felix Rebouças ${ }^{4}$, Kenya Waleria de Siqueira Coelho Lisboa ${ }^{4}$, Ana Maria Parente Garcia Alencar4, Edilma Gomes Rocha Cavalcante ${ }^{4}$
\end{abstract}

\section{Abstract}

This study aimed to describe the socio-demographic and clinical profile of elderly with diabetes mellitus in a Primary Health Care Unit. This is a descriptive and transversal study conducted in a city of Ceará State. The sample consisted of 55 elderly patients with type 2 diabetes mellitus. Data were collected from July to August 2014 through a socio-demographic and clinical variables form. The descriptive statistics was used for the analysis. The mean age of 71 years old was observed; $67.3 \%$ of the sample were women; $58.2 \%$ married; $30.9 \%$ illiterate; $83.6 \%$ with income less than two minimum wages; $61.8 \%$ were sedentary; $54.5 \%$ were overweight; $53.4 \%$ of grade I obesity; and $69.1 \%$ with altered postprandial glucose. The mean duration of the disease was more than 10 years, and diabetic complications were found. The elderly's profile can contribute to more health risks and serious impairment of quality of life.

1 Programa de Mestrado Acadêmico em Enfermagem, PMAE, Universidade Regional do Cariri, URCA, Crato, Ceará, Brasil.

2 Bolsista de Iniciação Científica, Fundação Cearense de Apoio ao Desenvolvimento Científico e Tecnológico, FUNCAP/URCA, Crato, Ceará, Brasil.

3 Faculdade de Medicina, Universidade Federal do Cariri, UFCA, Barbalha, Ceará, Brasil.

4 Departamento de Enfermagem, Universidade Regional do Cariri, Crato, Ceará, Brasil.

\section{Contact information:}

Jucier Gonçalves Júnior.

Address: 284, Divine Savior Street, Downtown, Barbalha, Ceará, Brazil, 63180000

Tel: $+55(88) 3312-5000$

\section{ほ juciergjunior@hotmail.com}

Health Profile; Diabetes Mellitus; Elderly.

\section{Introduction}

Diabetes mellitus (DM) is a clinical condition with an important social impact by the high incidence of hospitalization and premature death, regardless of the occurrence of associated risk factors [1]. In 2014, it accounted for 4.9 million deaths worldwide, mostly in low and middleincome countries. In Latin America, one in 12 adults has diabetes and 
is estimated to increase this number to $55.2 \%$ from 2014 to 2035. In this context, Brazil ranks fourth in the ranking of countries with mortalities resulting from DM [2].

It is estimated that the standardized prevalence rate of this disease increased from 2.9\% in 1998 to $4.3 \%$ in 2008 . The Midwest and Northeast recorded the most accented increase in coefficients, concluding that the prevalence of the disease is growing rapidly in Brazil [3].

In the elderly, recent data indicate a national prevalence of diabetes of $24.4 \%$, confirming a higher percentage of men, with $24.8 \%$ aged equal or higher than 65 years [4]. Elderly people with diabetes are more likely to develop peripheral neurologic and vascular complications in the lower members, as well as cardiovascular disease, affecting their productivity and daily activities, with repercussions that change the family role and social conviviality [5].

A national study conducted with elderly with a mean age of 79 years old in geriatrics clinic identified a high prevalence of peripheral artery disease associated with the presence of diabetes and smoking. Elderly people with diabetes and peripheral arterial disease have significant increase in cardiovascular morbidity and mortality, needing mortality prevention measures for this population [6].

In a systematic review of the literature, elderly with diabetes were found, presenting several factors that interfere with self-care ability, especially gender, economic status, educational level, duration and knowledge about the disease, highlighting the importance of nurses to identify such factors and to prioritize custom practices so they can reach the self-care management [7].

These data indicate the magnitude of diabetes in the elderly population, as well as the need for investigations that contribute to aggregate information about the knowledge of the epidemiological profile of these people, which may contribute to support health professionals in decision-making, regarding the development of preventive, promotion and DM treatment actions.

Given the above, the following question was formulated: Which is the profile of elderly patients with type 2 DM (DM2) accompanied in Primary Health Care? The objective of this study was to describe the socio-demographic and clinical profile of elderly with DM followed up in Primary Health Care.

\section{Method}

This is a descriptive and cross-sectional study, developed in a Primary Health Care Unit in the city of Juazeiro do Norte (CE), Brazil. The study population, selected through Health Status Report and Families Monitoring in the area/team of community health workers, was of 145 DM patients registered in the unit. After applying the inclusion criteria (age from 60 years old, DM2 diagnosis and to be accompanied by the health team of the unit), the sample resulted in 65 elderly patients with DM2. However, 10 elderly patients with DM2 were excluded, because they did not attend the health unit in the period of data collection, resulting in a final sample of 55 elderly patients eligible for the research.

The captivation of the elderly was as follows: after the explanation of the methods and objectives of the study, and having been made all relevant information, each participant proceeded to sign the Informed Consent Form, so the interviews and measurements were only made after their approval. For those who did not sign, the researcher read out the text and collected, immediately, the fingerprint of the participant in the document.

The data were collected in July and August 2014 by suitably qualified researchers, of the Primary Health Unit, in a room reserved for this purpose and during the attendance for diabetes patients scheduled for service. Thus, the data were obtained through a questionnaire containing socio-demographic variables such as gender, age group, profession, marital status, education, family income; and clinics, such 
as disease duration, type of drug treatment, alcohol use and smoking, physical activity, complications/ comorbidities, blood pressure measurements, blood glucose, weight and height.

Concerning the measurement of blood pressure, the techniques recommended in VI Guidelines of the Hypertension Brazilian Society were used [8], by indirect auscultation method, with aneroid sphygmomanometer duly calibrated and binaural stethoscope.

Initially, the procedure was explained to the elderly and instructed not talking during the measurement. It was certified that they were not with a full bladder; they have not practiced exercises for 60 minutes; have not consumed alcohol or coffee, and have not smoked in the previous 30 minutes. The measurement took place with the individual seated, uncrossed legs and supported on the ground. Soon after, the cuff was inserted in the middle of the arm, estimating the level of systolic blood pressure (SBP) and palpating the brachial pulse. After the measurement, the bell was located on the brachial artery, inflating to exceed $20 \mathrm{mmHg}$ of the obtained value. The SBP determinates the first Korotkoff sound auscultation, and diastolic blood pressure (DBP) for the disappearance or muffling the sound. Then, the values were recorded and reported to the individuals [8].

For the evaluation of the obtained prehistoric values, the following classification was used: great pressure to SBP $<120 \mathrm{mmHg}$ and DBP $<80 \mathrm{mmHg}$; normal for SBP $<130 \mathrm{mmHg}$ and $\mathrm{DBP}<85 \mathrm{mmHg}$; bordering for SBP 130 to $139 \mathrm{mmHg}$ and DBP 85 to $89 \mathrm{mmHg}$; stage 1 for SBP 140 to $159 \mathrm{mmHg}$ and DBP 90 to $99 \mathrm{mmHg}$; stage 2 hypertension for SBP 160 to $179 \mathrm{mmHg}$ and DBP 100 to $109 \mathrm{mmHg}$; hypertension stage 3 for SBP $\geq 180 \mathrm{mmHg}$ and DBP $\geq 110 \mathrm{mmHg}$ [8].

Concerning to capillary glucose, the measurement was performed with a punch at the distal face of the finger phalanx, as the participant's preference, obtaining the sample from a drop of blood, which reading was performed on the glucometer Accu-Chek Active brand. The value of glucose obtained on the measurer display has been interpreted as therapeutic targets to control postprandial glycemia of the Brazilian Diabetes Society (SBC) [5] and of the International Diabetes Federation (IDF) as normal $\leq 160 \mathrm{mg} / \mathrm{dL}$ and altered $>160 \mathrm{mg} / \mathrm{dL}$. It was only used postprandial because the capillary tests could not be performed with the fasting patients.

The weight was obtained in one shot, with the barefoot patient, with little clothing as possible, in the center of the machine upright, feet together and arms along the body and body weight distributed on both feet. [9] A digital and calibrated scale was used, Camry brand, with a maximum capacity of $150 \mathrm{~kg}$, with $100 \mathrm{~g}$ divisions and four sensor technology.

The height was also determined in a single measurement using an inelastic tape fixed to the wall with the zero point at ground level, with the patient in the upright position against the wall, parallel legs, not necessarily leaning, arms along the body, and head up looking at a fixed point at eye level. Before obtaining the measure, it was verified whether heels, calves, buttocks, shoulder blades and back of the head were leaning against the wall [9].

From the weight and height, the body mass index (BMI) was calculated, adopting the reference table for the elderly recommended by Lipschitz, with cutoffs points: low weight $\leq 22 \mathrm{~kg} / \mathrm{m}^{2}$; proper weight> 22 and $<27 \mathrm{~kg} / \mathrm{m}^{2}$; overweight $\geq 27 \mathrm{~kg} / \mathrm{m}^{2}$. This classification was adopted by stressing a greater risk range for malnutrition, considering the body changes resulting from the aging process, which provides a more accurate diagnosis [10].

The need to check which individuals in this classification range were in the obesity situation was perceived through the overweight cutoff point. To identify the obesity degree, the World Health Organization (WHO) table was adopted [11] from the following cut points: 25 to $<30$ pre-obese, 30 to 
$<35$ grade I obesity, 35 to $<40$ grade II obesity and $\geq 40$ grade III obesity.

Concerning the analysis of compliance with the Kappa [10] test, the value of 0.427 was verified, which is classified as moderate agreement between the cutoff points stipulated by Lipschitz and WHO, which allowed the obesity situation classification in this study, only to overweight individuals, according to the Lipschitz table, starting the pre-obese classification from the 27cutoff point.

The data were organized in a spreadsheet in Excel program, version 2013, and the descriptive statistics was adopted for the analysis. The data were presented in tables and analyzed according to the literature concerning the matter. The research was approved by the Research Ethics Committee of the Regional University of Cariri (URCA) under the CAAE 705,020 protocol, through the ethical requirements of the Resolution 466/2012.

\section{Results}

55 elderly patients with DM2 were investigated, with prevalence of females (67.3\%) and average of 71 years old (standard deviation - SD of 7.80; 60-93 years old); $58.2 \%$ of the elderly had incomplete Elementary School, with $78.1 \%$ of the female population, with significant illiteracy in the female population (52.9\%) and male (47.1\%). It was found that $58.2 \%$ of the elderly were married; of these, $53.1 \%$ were women; $78.2 \%$ were retired, of which $60.5 \%$ were women; and $83.6 \%$ of the elderly had a family income of one to two minimum wages. The remaining sample characteristics of the study for the socio-demographic variables are listed in Table 1; the percentages of male and female categories are calculated according to the proportion of the total of each variable.

The average number of residents per residence was from two to three people, but $26.1 \%$ of people with lower income had an average of six people at home.

Table 1. Socio-demographic profile of elderly people with type 2 diabetes mellitus, according to age, schooling, marital status, occupation, and family income. Juazeiro do Norte, Ceará, Brazil, 2014. (N=55).

\begin{tabular}{|c|c|c|c|c|c|c|}
\hline \multirow{2}{*}{ Variable } & \multicolumn{2}{|c|}{ Female } & \multicolumn{2}{|c|}{ Male } & \multicolumn{2}{|c|}{ Total } \\
\hline & N & $\%$ & N & $\%$ & N & $\%$ \\
\hline \multicolumn{7}{|l|}{ Age group } \\
\hline $60-69$ & 17.0 & 70.8 & 7.0 & 29.2 & 24.0 & 43.6 \\
\hline 70-79 & 15.0 & 68.2 & 7.0 & 31.8 & 22.0 & 40.0 \\
\hline 80 and more & 5.0 & 55.6 & 4.0 & 44.4 & 9.0 & 16.4 \\
\hline \multicolumn{7}{|l|}{ Schooling* } \\
\hline Illiterate $^{\dagger}$ & 9.0 & 52.9 & 8.0 & 47.1 & 17.0 & 30.9 \\
\hline Incomplete Elementary School (1 to 8 study years) & 25.0 & 78.1 & 7.0 & 21.9 & 32.0 & 58.2 \\
\hline Complete Elementary School (9 study years) & 1.0 & 50.0 & 1.0 & 50.0 & 2.0 & 3.6 \\
\hline Incomplete High School (10 to 11 study years) & 0.0 & 0.0 & 1.0 & 100.0 & 1.0 & 1.8 \\
\hline Complete High School (12 study years) & 1.0 & 50.0 & 1.0 & 50.0 & 2.0 & 3.6 \\
\hline Incomplete Higher Education (13 to 15 study years) & 0.0 & 0.0 & 0.0 & 0.0 & 0.0 & 0.0 \\
\hline Higher Education (average of 16 study years) & 1.0 & 100.0 & 0.0 & 0.0 & 1.0 & 1.8 \\
\hline \multicolumn{7}{|l|}{ Marital status } \\
\hline Married & 17 & 53.1 & 15.0 & 46.9 & 32.0 & 58.2 \\
\hline Divorced & 3.0 & 75.0 & 1.0 & 25.0 & 4.0 & 7.3 \\
\hline Single & 3.0 & 66.7 & 1.0 & 33.3 & 3.0 & 5.4 \\
\hline
\end{tabular}




\begin{tabular}{|c|c|c|c|c|c|c|}
\hline \multirow{2}{*}{ Variable } & \multicolumn{2}{|c|}{ Female } & \multicolumn{2}{|c|}{ Male } & \multicolumn{2}{|c|}{ Total } \\
\hline & $\mathrm{N}$ & $\%$ & $\mathrm{~N}$ & $\%$ & $\mathrm{~N}$ & $\%$ \\
\hline \multicolumn{7}{|l|}{ Marital status } \\
\hline Widower & 14.0 & 100.0 & 0.0 & 0.0 & 14.0 & 25.5 \\
\hline In a stable relationship & 1.0 & 50.0 & 1.0 & 50.0 & 2.0 & 3.6 \\
\hline \multicolumn{7}{|l|}{ Profession } \\
\hline Retired & 26.0 & 60.5 & 17.0 & 39.5 & 43.0 & 78.2 \\
\hline Pensioner & 4.0 & 100.0 & 0.0 & 0.0 & 4.0 & 7.3 \\
\hline Housekeeper & 5.0 & 100.0 & 0.0 & 0.0 & 5.0 & 9.1 \\
\hline Other activities & 2.0 & 66.7 & 1.0 & 33.3 & 3.0 & 5.4 \\
\hline \multicolumn{7}{|l|}{ Family income, Minimum wage ${ }^{\ddagger}$} \\
\hline $1-2$ & 33.0 & 71.7 & 13.0 & 28.3 & 46.0 & 83.6 \\
\hline $3-4$ & 3.0 & 50.0 & 3.0 & 50.0 & 6.0 & 10.9 \\
\hline$>5$ & 1.0 & 33.3 & 2.0 & 66.7 & 3.0 & 5.4 \\
\hline Total & 37 & 67.3 & 18 & 32.7 & 55 & 100 \\
\hline
\end{tabular}

Concerning the clinical variables, the elderly with DM2 were aware of their disease, on average, for 11.8 years (SD: $8.12 ; 5$ months to 40 years), $78.2 \%$ were only using oral hypoglycemic and $145 \%$ of oral hypoglycemic agents and insulin, while $7.3 \%$ did not make use of any drug therapy. The treatment with exclusive oral hypoglycemic, equivalent to monotherapy, was the most common among men and women, with $87.5 \%$ and $82.9 \%$, respectively.

It was found that $43.6 \%$ of the investigated elderly were former smokers, with a higher percentage of women with $66.7 \%$ and reported having failed to make use of that substance for an average of 26 years, with a maximum time of 63 years and a minimum of 2 years. Among the $16.4 \%$ smokers, the average of using time was 54 years, with an average of 5-6 smoked cigarettes per day. Among participants who used the cigarette, $55.6 \%$ were women.

It was evident that $7.3 \%$ of participants were current alcohol users, which corresponds to a percentage of $75 \%$ for men. An average consumption of 45 years was identified, with a maximum time of 49 years and a minimum of 42 years. $92.7 \%$ of participants who were not currently using alcohol (70.6\% women), 30.9\% have already consumed alcohol, which $70.6 \%$ were men.

$61.9 \%$ did not perform physical activity. Of the $38.1 \%$ who performed some exercise, $71.4 \%$ practices walking, $14.3 \%$ water aerobics, $4.8 \%$ popular gym and still 9.5\% performed the combined use of two physical activities (walking and water aerobics). The habit of physical activity was more common for women with $61.9 \%$, and the most practiced activity was walking for both sexes, of $71.4 \%, 66.7 \%$ were women, and 33.3\% were men. Among the complications and more cited comorbidities, $83.6 \%$ of the elderly had hypertension, $80 \%$ had ophthalmologic complications and $54.5 \%$ dyslipidemias. Gastrointestinal complications (38.2\%), cardiovascular (32.7\%), sexual dysfunction (25.5\%) and renal complications (9.1\%) were also identified among the elderly. It was also found that $27.3 \%$ of the participants had from one to two complications, $50.9 \%$ from three to four complications/comorbidities, $18.2 \%$ from five to six complications/comorbidities and $1.8 \%$ showed all mentioned complications/comorbidities. 
It was also found that $29.7 \%$ of women had SBP in borderline and 1 stages while $33.3 \%$ of men had SBP $<130 \mathrm{mmHg}$. Concerning DBP, $40.6 \%$ of women had value $<80 \mathrm{mmHg}$ and for men was $44.4 \%$.

Concerning postprandial glycemia, $70.3 \%$ of women and $66.7 \%$ of men had a value of $\geq 160 \mathrm{mg} /$ $\mathrm{dL}$. As for the evaluation of BMl among the elderly, $59.5 \%$ of female elderly had $\mathrm{BMI} \geq 27 \mathrm{~kg} / \mathrm{m}^{2}$, while in males, $55.6 \%$ had a BMl> $22 \mathrm{~kg} / \mathrm{m}^{2}$ and $<27 \mathrm{~kg} /$ $\mathrm{m}^{2}$.

Table 2. Clinical characteristics of elderly patients with type 2 diabetes mellitus, according to blood pressure, postprandial blood glycemia, body mass index (BMI) and obesity classification. Juazeiro do Norte, Ceará, Brazil, 2014. ( $\mathrm{N}=55)$.

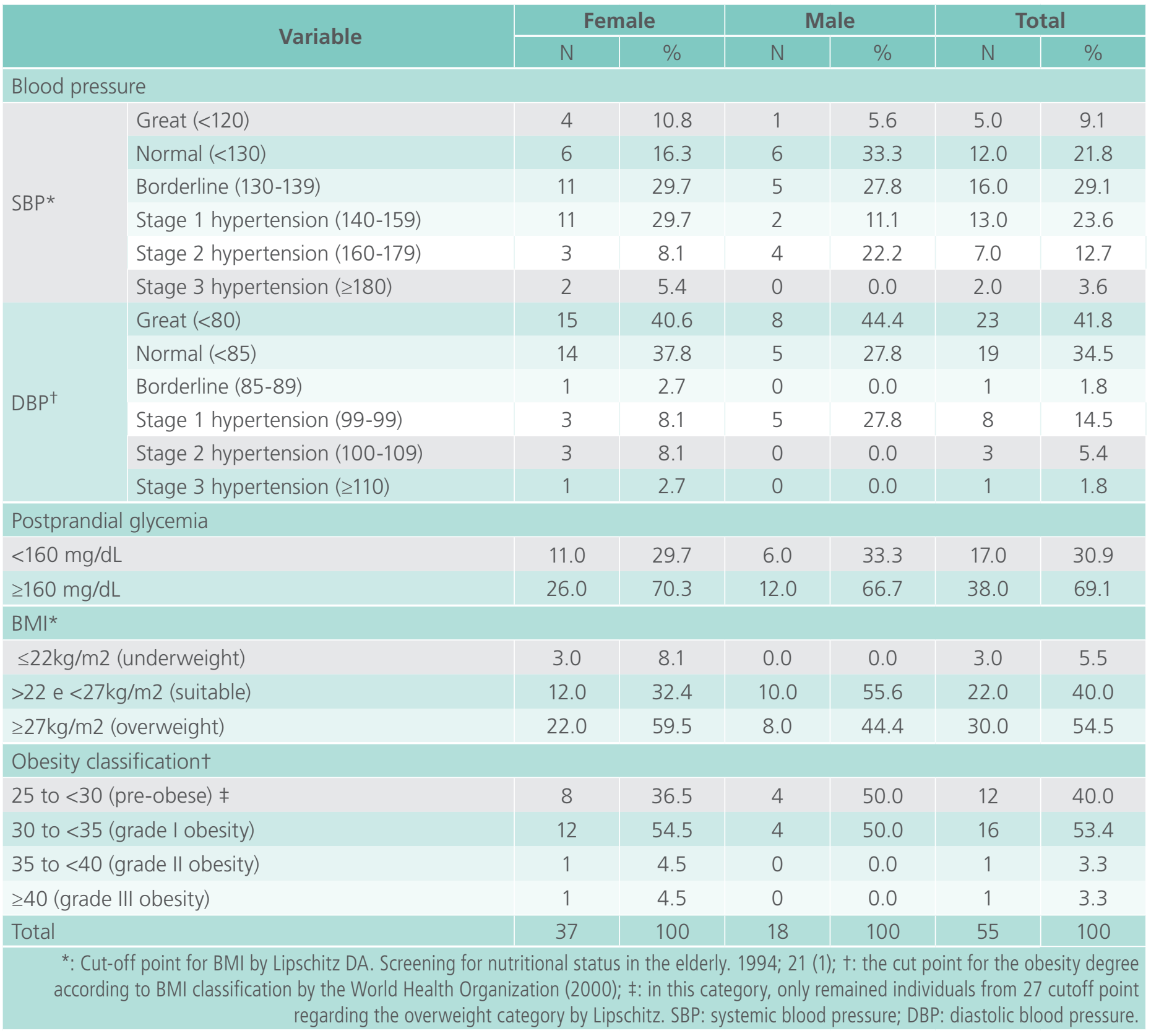




\section{Discussion}

It was found in this study that the majority of elderly patients with DM were female, married, with low education and survived with minimal income. This socio-economic and epidemiological profile corroborates similar studies developed in the Northeast and Southeast Brasil [12, 13].

This significant difference for the female is justified in the literature by the fact that women have higher life expectancy, tendency to take care more than men and seek more frequently for health care service, facilitating early diagnosis, compared to men, which have lower demand for health $[12,14]$. Another hypothesis is that older women are more likely to develop chronic diseases and comorbidities, due to hormonal drop in the climacteric phase [15].

Concerning marital status, the prevalence of married elderly is consistent with studies about the profile of elderly conducted in Minas Gerais [14] and Fortaleza (CE) [16], noting a higher percentage of males because it is considered the fact that many men remarry after the death of their wives, reflecting habits culturally diffused between generations, according to which the woman, after the spouse death, must remain a widow to assume exclusive dedication to home care and children [16].

In this study, we found that an extract of participants with lower income had a significant number of people in the residence, corroborating the data found in a study performed with elderly with diabetes in Minas Gerais, which also identified the relevant prevalence of $35.4 \%$ for participants with more people in residence [17]. Given the low socioeconomic status and the need for per capita division between the family/aggregated found in this study, one can assume its direct relation to the supply conditions, which interfere directly in diabetes control.

The schooling and income reflect the health status of the population, as elderly with more education, and higher income is more independent for self-care, the use of transportation and communication, and has good adhesion to the correct use of medicines. Elderly people with low education and income are more vulnerable to the risks of DM complications and health problems, and to the commitment of the treatment, since the incomes are insufficient to meet the standard of the elderly needs and their family [17]. Thus, it reaffirmed the individual and social vulnerabilities to which these people are exposed, being a reading reality and important, to be perceived by the health team, especially the nurse, for, together with the patient, to trace possible interventions.

About the clinical profile, the patients evaluated in the present study had a mean DM knowledge time of more than 10 years, confirming research data developed in Belo Horizonte (MG) [12]. This finding is worrisome, since prolonged diabetes, associated with poor metabolic control, can predispose the elderly to chronic complications, which are responsible for high morbidity and mortality, and increased cardiovascular mortality, renal, in the amputation of the lower limbs and decreased the quality of life [18]. In this sense, the monitoring of these diseases, the prevention of disabilities and health promotion should be the focus for effective control of chronic diseases in Primary Care

Regarding drug therapy, the use of only oral hypoglycemic was more prevalent among the surveyed elderly people. The Brazilian Diabetes Society advocates individualized treatment for elderly patients with diabetes, considering life expectancy, associated comorbidities, polypharmacy, self-care ability, family support, and the hypoglycemia costs and risks. The need for greater attention to the prescription of other drugs was emphasized, such as insulin and other oral hypoglycemic agents, being not too permissive with the elderly hyperglycemia [18]. Considering these fragilities, it is worth noting the importance of observing the responses of the elderly to drugs, which are not always valued by health professionals in services, at any assistance level.

Smoking and alcohol were present habits among surveyed elderly, whose data corroborate those found in the study by Sousa et al. [13] with the 
presented highest percentage of men (21.7\%) in the consumption of alcohol and the prevalence of women (56.7\%) in the cigarette consumption.

Tobacco smoking has harmful effects, such as impaired glycemic control, more probability to develop neuropathy and retinopathy, and serious implications for the cardiovascular system, resulting in peripheral vasoconstriction, increased heart rate and blood pressure, and cause damage to blood vessel walls, favoring the formation of atherosclerotic plaques, which have intrinsic relationship with the diabetic foot [19]. Thus, the progressive abandonment of the cigarette for DM elderly is recommended and strengthening educational actions in health developed by health professionals working in Primary Care to control this serious risk factor.

Although alcohol has presented a low percentage of use among the elderly of this study, it is considered another important risk factor for DM because potentiates the hypoglycemic effects of drugs and aggravates neuropathic symptoms. In this case, the patient should be advised to reduce the use and gradually, referring consumption, should prefer drinks with low alcohol content and always associated with the consumption of foods rich in carbohydrates hydrated, to avoid the hypoglycemic effects [20].

Concerning physical activity, it was found that it is still an emerging practice among the study participants and those who practiced it cited the walk as the most accomplished exercise. The prevalent sedentary lifestyle among the elderly was also evidenced in another study, with $62.3 \%$ of men and $62.5 \%$ of women without physical activity practice [13].

It is inferred that this result may be related to common limitations among elderly with diabetes, such as osteoarthrosis, arthritis, tremors, stroke sequelae, among others, often hindering for physical activity in this population. Thus, the general conditions of the elderly should guide the prescription of physical activity, and cardiovascular assessment of this group should be routine in the clinical practice [5].

Physical activity improves functional capacity in elderly patients with and without diabetes, being advocated a risk assessment before indicating an activity program, which synchronicity and exercise type should be considered related to the therapeutic regimen. To facilitate increased adhesion of the elderly with diabetes to physical activity, it indicates an exercise program in a group or community, under the monitoring of a physical educator [18].

It is suggested to the functional independent DM elderly, to perform the goals recommended for adults with diabetes. Elderly people with some dependence degree must follow a low-intensity exercise program to improve performance and mobility and, if possible, a physical therapist should be consulted, especially for those who live alone, bedridden or are confined to a chair, to improve physical performance and strength of the lower limbs, and prevent further deterioration in the functional state [18].

A sedentary lifestyle may be associated with overweight and obesity evidenced in the women of the study. Similar data was found in research conducted in Piauí, where $61.4 \%$ of overweight people were female [20]. As for the higher prevalence of obesity among the studied elderly women, the data is according to research carried out in São Paulo. This fact can be explained by the fact that women are more prone to the accumulation of fat and have a greater tolerance to excess body fat [21].

Considering physical activity as important in weight control, it is emphasized the need of a multidisciplinary team of Primary Health Care to partner with healthcare professionals of the Support Center for Family Health (NASF) for better monitoring of patients, encouraging them to change behavioral habits and the formation of interactive groups to exchange knowledge and practice of physical exercise. 
Regarding the presence of complications and comorbidities of participants in this study, it was found that most had three to four comorbidities/concomitant complications, among them systemic arterial hypertension, ophthalmologic complications, and dyslipidemia. In other studies, hypertension was also more frequent in the sample population [12], as well as the presence of visual complications (retinopathy, blindness or severe visual impairment) [14, 22] .Considering the time of diabetes and the presence of comorbidity, these patients needs monitoring and constant tracking, which include the need for referrals to specialized services, test routines, and other services to ensure comprehensive care and the highest quality of life.

About glycemic control, primordial in the prevention of chronic complications of diabetes, abnormal glucose was found in the study population, which support the data found in many studies performed with DM elderly [23, 24].

It was found, in the literature, that although the elderly know the importance of glucose monitoring and performing it, most show high levels of glucose, which are associated with excess weight, abdominal obesity, high blood pressure and insufficient levels of physical activity [13].

The goals for glycemic control must be established in an individual way, considering the functional status, comorbidities, the risk for hypoglycemia, and the presence of microvascular complications [18].

Concomitantly, the health professional must pay attention to the independent variables associated with the lack of glycemic control, such as obesity and poor adherence to antidiabetic drugs. An education program that emphasizes the importance of medication adherence, physical exercise and weight control would be a relevant basic benefit for improving glycemic control in this patients [24].

The decompensated DM can cause clinical complications affecting the heart and blood vessels, eyes, kidneys and nerves, which, therefore, collaborate to the emergence of cardiovascular disease, blindness, kidney failure and amputation of lower limbs. It also emphasizes that these people are at higher risk for infections and sleep apnea [2].

In the face of health injuries which may be caused, health professionals should advise patients and families about the importance of maintaining the recommended glycemic patterns and glycemic control alternatives being agreed and offered.

The evidence of this study reinforce the importance of periodic clinical assessment, with strict control of blood pressure, glycemia and weight, according to the guidelines of the Ministry of Health, regarding the control of risk factors and daily care with food and with feet of people with diabetes in Primary Health Care because in this way, the early monitoring of complications and comorbidities is facilitated. Health staff actions of Primary Care must be guided in a holistic and comprehensive care to people with diabetes [25].

\section{Conclusions}

It was found a socio-demographic profile of elderly with diabetes, female, married, with low educational level and who survived with minimal income. Concerning the clinical profile, the evaluated patients showed a duration of diabetes mellitus greater than 10 years, especially the use of oral hypoglycemic agents, incipient physical activity, low glycemic control, and most overweight and grade I obesity, and were also observed complications and concomitant comorbidities, such as hypertension, ophthalmological, gastrointestinal and dyslipidemias, culminating in greater risks to health and seriously compromise of the quality of life.

The limitations of this research are related to the cross-sectional design, which does not allow the determination of the cause and effect between variables. However, through the used methods and approaches, it was possible to trace the socio-demographic and clinical profile of a representative sample of the population with type 2 diabetes me- 
Ilitus in the unit under study. These results can contribute to health interventions planning with a focus on biological, cultural and social user dimensions, able to meet the needs access to network services and the active participation of individuals, providing opportunities thus, greater support for the health professional to decision making.

\section{Collaborations}

Fabricio NP and Sousa ND contributed to the conception, design, analysis and interpretation of data, article writing and relevant critical review of the intellectual content. Gonçalves Júnior J, Lisbon KW, Alencar AM and Cavalcante EGR contributed to the writing of the article, relevant critical review of the intellectual content and final approval of the version to be published.

\section{Acknowledgments}

To the health professionals from Primary Health Care Units of the study, of Juazeiro do Norte municipality (CE). To the Integrated Center for Diabetes and Hypertension of Barbalha (CE), for the availability of space for training and calibration of instruments.

\section{Conflict of Interest}

The Authors declare they not conflict of interest

\section{References}

1. Emerging Risk Factores Collaboration. Diabetes mellitus, fasting glucose, and risk of cause-specific death. N Engl J Med. 2011; 364(9):829-41.

2. International Diabetes Federation (IDF). IDF diabetes atlas [Internet]. 6. ed. International Diabetes Federation; 2014 [citado 17 mar 2016]. Disponível em: http://www.idf.org/sites/default/ files/EN 6E Atlas Full 0.pdf

3. Freitas LR, Garcia LP. Evolução da prevalência do diabetes e deste associado à hipertensão arterial no Brasil: análise da Pesquisa Nacional por Amostra de Domicílios, 1998, 2003 e 2008. Epidemio. Serv. Saúde. 2012; 21(1):7-19.
4. Brasil. Ministério da Saúde. Vigitel Brasil 2014: vigilância de fatores de risco e proteção para doenças crônicas por inquérito telefônico [Internet]. Brasília, DF: Ministério da Saúde; 2015 [citado 17 mar 2016]. Disponível em: http://bvsms.saude.gov.br/ bvs/publicacoes/vigitel brasil 2014.pdf

5. Sociedade Brasileira de Diabetes (SBD). Tratamento de pacientes idosos. In: Sociedade Brasileira de Diabetes (SBD). Diretrizes da sociedade brasileira de diabetes. São Paulo: A.C. Farmacêutica; 2016. p. 294-300.

6. Turrini FJ, Ventura MM. Prevalência de doença arterial periférica em idosos atendidos no ambulatório de geriatria e sua correlação com fatores de risco cardiovascular. UNOPAR Cient Ciênc Biol Saúde. 2011; 13(1):17-21.

7. Tanqueiro MT. A gestão do autocuidado nos idosos com diabetes: Revisão sistemática da literatura. Rev. Enf Ref. 2013; III série (9):151-60.

8. Sociedade Brasileira de Cardiologia (SBC), Sociedade Brasileira de Hipertensão $(\mathrm{SBH})$, Sociedade Brasileira de Nefrologia (SBN). VI Diretrizes Brasileiras de Hipertensão. Arq Bras Cardiol [Internet]. 2010 [citado 17 mar 2016]; 95(1supl.1); 1-51. Disponível em: http://publicacoes.cardiol.br/consenso/2010/ Diretriz hipertensao ERRATA.pdf

9. Brasil. Ministério da Saúde. Secretaria de Atenção à Saúde. Departamento de Atenção Básica. Orientações para a coleta e análise de dados antropométricos em serviços de saúde: Norma Técnica do Sistema de Vigilância Alimentar e Nutricional (SISVAN) [Internet]. Brasília, DF: Ministério da Saúde; 2011 [citado 17 mar 2016]. Disponível em: http://189.28.128.100/ dab/docs/portaldab/publicacoes/orientacoes coleta analise dados_antropometricos.pdf

10. Souza R, Fraga JS, Gottschall CB, Busnello FM, Rabito El. Avaliação antropométrica em idosos: estimativas de peso e altura e concordância entre classificações de IMC. Rev Bras Geriatr. Gerontol. 2013; 16(1):81-90.

11. World Health Organization (WHO). Obesity: preventing and managing the global epidemic: report of a WHO consultation. Geneva: WHO; 2000.

12. Lima AP, Pereira DA, Romano VF. Perfil sócio-demográfico e de saúde de idosos diabéticos atendidos na atenção primária [Internet]. Rev Bras Ciências da Saúde. 2011 [citado 17 mar 2016].; 15(1):39-46. Disponível em: http://periodicos.ufpb.br/ ojs/index.php/rbcs/article/viewFile/9911/5813

13. Sousa JT, Macêdo SF, Moura JR, Silva AR, Vieira EE, Reis AS. Autocuidado e parâmetros clínicos em pacientes com diabetes mellitus tipo 2. Rev Rene. 2015; 16(4):479-5.

14. Santos EA, Tavares DM, Rodrigues LR, Dias FA, Ferreira PC. Morbidades e qualidade de vida de idosos com Diabetes Mellitus residentes nas zonas rural e urbana. Rev Esc Enferm USP [Internet]. 2013 [citado 17 mar 2016]; 47(2):393-400. Disponível em: http://www.scielo.br/pdf/reeusp/v47n2/17.pdf 
15. Sociedade Brasileira de Cardiologia (SBC). I Diretriz Brasileira sobre Prevenção de Doenças Cardiovasculares em Mulheres Climatéricas e a Influência da Terapia de Reposição Hormonal (TRH) da Sociedade Brasileira de Cardiologia (SBC) e da Associação Brasileira do Climatério (SOBRAC). Arq Bras Cardiol. 2008 [citado 22 mar 2016]; 91(1 Supl. 1):1-23. Disponível em: http://publicacoes.cardiol.br/consenso/2008/diretriz DCV mulheres.pdf

16. Clares JW, Freitas MC, Almeida PC, Galiza FT, Queiroz TA. Perfil de idosos cadastrados numa unidade básica de saúde da família de Fortaleza-CE. Rev Rene [Internet]. 2011 [citado 17 mar 2016]; 12 (n.esp.):988-94. Disponível em: http://www.revistarene.ufc. br/vol12n4 esp pdf/a14v12esp n4.pdf

17. Viegas-Pereira AP, Rodrigues RN, Machado CJ. Fatores associados à prevalência de diabetes auto-referido entre idosos de Minas Gerais. R Bras Est Pop [Internet]. 2008 [citado 17 mar 2016]; 25(2):365-76. Disponível em: http://www.scielo.br/pdf/ rbepop/v25n2/v25n2a11.pdf

18. International Diabetes Federation (IDF). Guideline for managing older people with type 2 diabetes [Internet]. 2013 [citado 17 mar 2016]. Disponível em: http://www.idf.org/guidelines-olderpeople-type-2-diabetes

19. Hocayen PA, Malfatti CR. Tabagismo em pacientes diabéticos: predisposição às doenças crônico-degenerativas e neoplasia. Rev Cinergis [Internet]. 2010 [citado 17 mar 2016]; 11(2):19-25. Disponível em: https://online.unisc.br/seer/index.php/cinergis/ article/view/2056/1637

20. Nogueira AM, Temóteo TL, Carvalho CM, Carvalho AM, Borges $\mathrm{ME}$, Luz $\mathrm{MH}$, et al. Estudo multidimensional de idosos diabéticos atendidos em ambulatório do sistema único de saúde. Rev Enferm UERJ [Internet]. 2010 [citado 17 mar 2016]; 18(1):25-31. Disponível em: http://www.facenf.uerj.br/v18n1/v18n1a05.pdf

21. Aurichio TR, Rebelatto JR, Castro AP. Obesidade em idosos do Município de São Carlos, SP e sua associação com diabetes melito e dor articular. Fisioterapia e Pesquisa [Internet]. 2010 [citado 17 mar 2016]; 17(2):114-7. Disponível em: http://www. scielo.br/pdf/fp/v17n2/04.pdf

22. Lima CT, Kanno DT, Gonsalles MC, Assis DM, Gianesella ES. Diabetes e suas comorbidades no Programa de Saúde da Família Vila Davi em Bragança Paulista, SP. Rev Bras Clin Med [Internet]. 2010 [citado 17 mar 2016]; 8(4):316-9. Disponível em: http:// files.bvs.br/upload/S/1679-1010/2010/v8n4/a005.pdf
23. Cardozo AC, Martins CR. Correlação entre o envelhecimento e a hereditariedade no desenvolvimento de diabetes mellitus tipo 2: um estudo transversal analítico. Revista de Divulgação Científica Sena Aires [Internet]. 2012 [citado 17 mar 2016]; 2:133-40. Disponível em: http://revistafacesa.senaaires.com.br/index.php/ revisa/article/view/23/17

24. Kamuhabwa AR, Charles E. Predictors of poor glycemic control in type 2 diabetic patients attending public hospitals in Dar es Salaam. Drug Healthc Patient Saf. 2014; 6:155-65.

25. Brasil. Ministério da Saúde. Resolução n 466, de 12 de dezembro, 2012. Aprova as diretrizes e normas regulamentadoras de pesquisas envolvendo seres humanos. [Internet]. Diário Oficial da União. 2013 jun. 13 [citado 17 mar 2016]. Disponível em: http://conselho.saude.gov.br/resolucoes/2012/Reso466.pdf
Publish in International Archives of Medicine

International Archives of Medicine is an open access journal publishing articles encompassing all aspects of medical science and clinical practice. IAM is considered a megajournal with independent sections on all areas of medicine. IAM is a really international journal with authors and board members from all around the world. The journal is widely indexed and classified Q1 in category Medicine. 